\title{
Deinococcus prospects
}

\section{Michael J. Daly}

I think that the comments on my Opinion article (A new perspective on radiation resistance based on Deinococcus radiodurans. Nature Rev. Microbiol. 7, 237-245 (2009)) $)^{1}$, by Zhang and colleagues (Antioxidants used by Deinococcus radiodurans and implications for antioxidant drug discovery. Nature Rev. Microbiol. (10.1038/nrmicro2073-c1)) ${ }^{2}$ are reasonable. The existence of chemical antioxidant protectants in bacteria ${ }^{1}$ makes one wonder whether equivalent processes may be acting in higher organisms. I agree with Zhang and colleagues that we might be able to develop novel pharmaceuticals to fight oxidative stress if we could elucidate the mechanisms developed by Deinococcus radiodurans to protect its key macromolecules. My colleagues and I have been working hard to identify the molecular agents which provide that protection and, indeed, Zhang and colleagues are correct in their prediction that there is more than one compound (E.K. Gaidamakova, V.Y. Matrosova, J.G. Kiang, N.B. Wehr, G. Viteri, B.S. Berlett,
R.L. Levine and M.J.D., unpublished observations). There is a growing realization that $D$. radiodurans did not evolve new antioxidant or DNA repair proteins, but rather that it found a way to protect conventional enzymes and use them more efficiently ${ }^{3}$. Since the 1960s, the goal of exporting those protective processes outside of the host cell for practical purposes has eluded research$\mathrm{ers}^{4}$. I think the day on which this goal will be achieved is not far off.

$$
\begin{array}{r}
\text { Michael J. Daly is at the Uniformed Services } \\
\text { University of the Health Sciences Bethesda, } \\
\text { Maryland 20814, USA. } \\
\text { e-mail: mdaly@usuhs.mil }
\end{array}
$$

1. Daly, M. J. A new perspective on radiation resistance based on Deinococcus radiodurans. Nature Rev. Microbiol. 7, 237-245 (2009).

2. Zhang, H.-Y., Li, X.-J., Gao, N. \& Chen, L.-L. Antioxidants used by Deinococcus radiodurans and implications for antioxidant drug discovery. Nature Rev. Microbiol. (10.1038/nrmicro2073-c1).

3. Galhardo, R. S. \& Rosenberg, S. M. Extreme genome repair. Cell 136, 998-1000 (2009).

4. Bruce, A. K. Extraction of the radioresistant factor of Micrococcus radiodurans. Radiat. Res. 22, 155-164 (1964). 